\title{
Diagnostic aspects and in-service training in the decentralization of care to people living with HIV*
}

\author{
Aspectos diagnósticos e capacitações em serviço na descentralização \\ do atendimento às pessoas vivendo com HIV \\ Aspectos diagnósticos y formación en servicio en la descentralización \\ de la atención a las personas que viven con el VIH
}

How to cite this article:

Lima MCL, Pinho CM, Dourado CARO, Silva MAS, Andrade MS. Diagnostic aspects and in-service training in the decentralization of care to people living with HIV. Rev Esc Enferm USP. 2021;55:e20210065. https://doi.org/10.1590/1980-220X-REEUSP-2021-0065

\section{Morgana Cristina Leôncio de Lima ${ }^{1}$ \\ Clarissa Mourão Pinho' \\ Cynthia Angélica Ramos de Oliveira Dourado $^{1}$}

\section{Mônica Alice Santos da Silva ${ }^{1}$ \\ Maria Sandra Andrade ${ }^{1}$}

* Extracted from the dissertation: "Percepção do enfermeiro sobre a descentralização do atendimento às pessoas vivendo com HIV/Aids para atenção primária à saúde à luz da teoria de Imogene King”, Programa Associado de Pós-Graduação em Enfermagem, Universidade de Pernambuco/ Universidade Estadual da Paraíba, 2020.

${ }^{1}$ Universidade de Pernambuco, Programa Associado de Pós-Graduação em Enfermagem, Recife, PE, Brazil.

\begin{abstract}
Objective: To analyze the perception of nurses on the decentralization of care to people living with HIV. Method: Exploratory, descriptive, qualitative study conducted with primary health care nurses based on Imogene King's Open Systems Theory (personal, interpersonal, and social). The data were obtained through interviews; a sociodemographic/professional questionnaire and a semi-structured script were employed, processed by the IRAMUTEQ software and analyzed through Descending Hierarchical Classification. Results: Study participants amounted to 32 nurses. Five classes emerged from the analysis: "diagnostic revelation process"; "professional training"; "preventive measures"; "barriers and potentials in the process of decentralization"; and "stigma and prejudice". Conclusion: In the process of reorganization of the healthcare model for people living with HIV in primary health care, an important contribution by nurses in strengthening the local healthcare decentralization was identified.
\end{abstract}

\section{DESCRIPTORS}

HIV; Acquired Immunodeficiency Syndrome; Primary Health Care; Nursing. 


\section{INTRODUCTION}

Brazil has been advancing in healthcare provided to People Living with HIV (PLHIV). Changes in the healthcare system proposed by the Ministry of Health in 2014 established shared care with the Specialized Care Service (Serviço de Assistência Especializada - SAE) through decentralization of care to Primary Health Care (PHC) ${ }^{(1)}$.

In this perspective, the new directives enable broadening the detection of the Human Immunodeficiency Virus (HIV) infection through Rapid Test (RT) and make the PHC a protagonist in the SDT and AIDS Policy. Consequently, early identification of the disease promotes higher therapeutic adherence and a strengthened bond between professionals and service users, considered essential to direct the reorganization of the locally proposed model ${ }^{(2-4)}$.

In comparison with other countries, decentralization is found to be particularly more consolidated in African countries, where there is a high prevalence of $\mathrm{HIV}^{(5,6)}$. Studies carried out in Malawi and a district of Uganda have shown, among advancements in PHC follow-up, increased testing, treatment coverage, reduction of distances from the health services and reduction of expenses with transportation and food ${ }^{(5,7)}$.

However, some barriers to the decentralization of PHC are still verified. The main reasons are related to the proximity of user houses to PHC, which leads to fear of diagnosis exposure and discrimination, in addition to satisfaction with treatment in the specialized centers ${ }^{(8)}$.

This context implies the relevance of conducting studies to analyze the process of decentralization, as well as to verify positive aspects and possible barriers to reorganization of care to people living with HIV in primary health care. Therefore, the study had the objective of analyzing the perception of nurses on decentralization of care to people living with HIV.

\section{METHOD}

\section{Design of Study}

This is an exploratory, descriptive, qualitative field study based on Imogene King's Theory of Goal Attainment, which has three open systems (personal, interpersonal, social) as a presupposition, focused on the interaction of nurse and patient with their environment ${ }^{(9)}$.

\section{Study Participants}

The study participants were nurses who were part of the PHC Family Health Strategy (FHS) in the municipality of Recife, capital of the state of Pernambuco, Brazil. Regarding the health sector, the city is divided into eight Sanitary Districts, which are operational management units of the territories distributed into approximately 94 neighborhoods. The city has 131 Family Health Units (FHU) with 276 teams and 1 SAE managed by the municipality's administration. The study was conducted in 27 FHU.

The sample was selected following the orientation of the manual of the software Interface de $R$ pour les
Analyses Multidimensionnelles de Textes et de Questionnaires (IRAMUTEQ), which considers 20 to 30 texts as a satisfactory number for analysis ${ }^{(10)}$. Guided by this number, sample size was determined by the data saturation criterion. The sample was completed when the information became redundant, showing that the discourses had been exhausted, being unable to complete or contribute with new information ${ }^{(11)}$.

\section{Selection Criteria}

Bedside nurses of both sexes with at least one year of FHS took part in this study. Nurses in management or coordinating positions in FHS or bedside nurses who were on medical or maternity leave or had been dismissed for other reasons for longer than three months were excluded.

\section{Data Collection}

The data were collected from December 2019 to March 2020. For such, the following were employed: a questionnaire with the variables age, sex, years of education, years working in PHC, other employment bonds and complementary education; and interviews directed by guiding questions related to care to people living with HIV/AIDS, which dealt with access, diagnosis, structure, trainings, prevention activities, and health education.

The collection was performed by two nurse researchers who are not part of the staff of the studied FHU. Study participants were invited and informed of the research objective. They were not acquainted with the researchers.

The interviews were conducted in a site indicated by the professionals in the health service; these were scheduled in advance. The reports were recorded with participant permission and the mean duration of each interview was 40 minutes. After the interviews, the speeches were thoroughly transcribed and identified by the letter $\mathrm{E}$ (for enfermeiros, i.e., Portuguese for "nurses") followed by the sequence of interviews with the objective of preserving participant identity.

\section{Data Analysis and Treatment}

For data processing and organization, the software IRAMUTEQ was employed. From the possibilities of analysis made available in this software, Descending Hierarchical Classification (DHC) was employed for qualitative data analysis. This initially divides the corpus into Text Segments (TS) by word frequency, and into Elementary Context Units (ECU), organizing the data into illustrative dendrograms which show the relations and words of each class ${ }^{(10)}$. In this study, words with frequency $\geq 8$, chi-squared $\left(x^{2} \geq 3.84\right)$, and $\mathrm{p}<0.001$ were considered.

Upon data processing through the software, 1,122 TS were obtained; in DHC analysis, utilization of the initial corpus was $87.61 \%$; in class formulation, 983 TS were considered.

For data systematization, the thematic modality of Bardin's content analysis ${ }^{(11)}$ was employed. The interpretive corpus analysis was supported by the theoretical framework of Imogene King published in 1981, an explanatory model 
based on the Theory of Goal Attainment, represented by the personal, interpersonal, and social open systems ${ }^{(9)}$. This approach promoted an understanding of the care provided to PLHIV in PHC, considering the nurses' perceptions.

\section{Ethical Aspects}

This research has abided by the ethical aspects for studies involving human beings as per Resolution n. 466/2012 by the National Health Council of the Brazilian Ministry of Health, approved by the Research Ethics Committee of University Hospital Oswaldo Cruz/Pronto-Socorro Cardiológico de Pernambuco (CEP HUOC/PROCAPE) on opinion 2.224.605, dated 2017. After accepting study participation, all participants signed the Informed Consent Form (ICF).

\section{RESULTS}

The sample was composed of 32 nurses, most of which (96.9\%) were female. Minimum age was 31 years old and maximum was 66 years old; the mean was 45.75 years old. Regarding professional profile, $46.9 \%$ of nurses reported 16 to 25 years of education and an experience of 10 to 20 years (59.4\%) working in PHC; 68.8\% had an additional employment bond. Concerning complementary education, $34.4 \%$ had completed a family health postgraduate program.

Regarding the classes obtained through partition of the initial corpus, dendrogram is suggested to be read from left to right, bottom-up. The corpus was divided into two ramifications: the first, including Class 2, which comprises two sub-corpora with ECU (15.46\%), and Class 3, with ECU (15.36\%), presented similar percentages; the other comprised Class 1, with ECU (25.13\%), corresponding to 247 TS, which was further divided into Class 4 (23.91\%), with 235 TS, and Class 5 (20.14\%), compatible with 198 TS, represented in the dendrogram (Figure 1).

The interpretive analysis of the textual data enabled the identification of the following classes: diagnostic revelation process, professional training, preventive measures, barriers and potentials in the process of decentralization, and stigma and prejudice. From these five classes, accordance with the systems proposed by King were pointed out. The systems are emphasized to have mutual interaction and, thus, they cannot be considered in isolation; the division is visualized by the predominance of the classes in each system.

\section{Interpretive Analysis of the Classes}

Class 1, Process of HIV diagnostic revelation, permeates contents related to diagnosis methods and their respective implications after result disclosure. Based on Imogene King's Theory, it aims at strengthening the process of diagnostic acceptance through therapeutic interaction between nurse and patient, which is crucial to establish the effective healthcare process, in which the fundamental axis is observed to be initial communication through interpersonal relations based on safety and reliability.

Thus, barriers to diagnosis communication may constitute a hindrance to the establishment of interpersonal relations, as shown in the following utterances:

The only thing I want is support, at least someone as backup, because when a positive result shows up, I don't think I'll be brave enough to communicate this result (E29).

It's horrible, as a professional, to communicate a positive HIV result, no matter how qualified we are, how much technical and scientific knowledge on the virus we have, when the result is positive, we always keep thinking ... For God's sake! How am I going to say this? (E12).

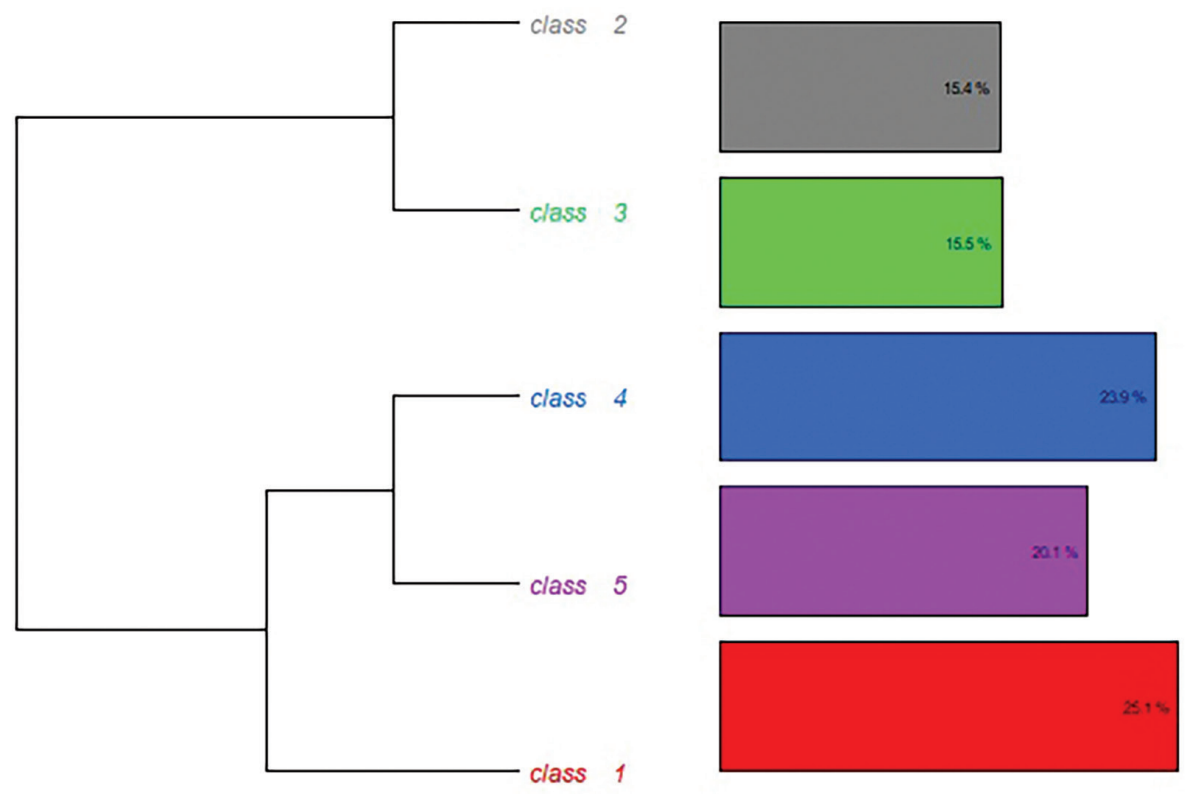

Figure 1 - Dendrogram of the classes from the textual corpus. Recife (PE), Brazil, 2020.

Source: IRAMUTEQ 0.7 alpha 2, 2014. 
The study mentions aspects which help the professional in the moment of diagnostic revelation, i.e., knowledge of HIV management and treatment and flows established in the Healthcare Network (HN), with impacts on nurse safety in decision-making and care conducts:

I've provided results, I feel confident, because I know good treatment is offered in Brazil, I'm just worried that this will be neglected by current government managers from the federal to the municipal level (E08).

In Class 2, Professional training, discourses related to professional training are pointed out as an important pillar in the process of decentralizing care to PLHIV, in which being up-to-date, habilitation, and sensibilization to integral care in face of HIV are emphasized.

In the nurses' statements, an important step was noticed concerning the introduction of trainings on the local management planning; however, a thematic limitation of trainings targeted at the execution of the rapid test, in addition to directing the offer of trainings to nurses, is still noticed:

It's beyond my limits to offer the rapid test to everyone, this is a huge demand for a nurse. My doctor and dentist do not provide the rapid test, because they were not included in the training (E08).

(...) Every six months there is a new training; concerning qualification for rapid test, they want to provide it only to nurses, and then our unit is not offering it, because all professionals should adhere, not only nurses (E22).

Class 3, Preventive measures, reveals contents targeted at health education as a meaningful tool that enables a professional approach in actions and activities of health promotion and prevention. It aimed at responding to individual, family, and collective necessities associated to the community's social, economic, and cultural contexts. Based on the theory proposed by Imogene King, the exchange of experience and knowledge between the nurse working in PHC and health users, through health education, is related to the interpersonal system, which composes the triad of the theory in which strengthening multiple health spaces is enabling achieving goals which were established in the healthcare plan:

The health education activities are carried out every day in the waiting room and there are educational talks in which we discuss sexual infections and HIVIAIDS (E25).

The health education activities are implemented in pregnant women's groups, in schools (...) (E32).

In Class 4, Barriers and potentials in the process of decentralization, through the most frequent words in the participants' utterances, negative and positive aspects regarding guarantee and access to care offered by the health system through PHC are observed. Barriers related to network flow, precariousness, and inappropriate physical structure of the PHC and supply deficit are emphasized. Additional limitations requiring attention are related to the following human resources: work overload; lack of training; and care responsibility attributed to one category among the FHS team:

We know that as nurses assume this responsibility, it will become an additional workload, a buge responsibility, particularly when communicating a positive rapid test (E20).

(...) whether we like or not, primary care, even if we try to help, there is a point in which this becomes impossible (...) the negative point is the lack of physical structure (E20).

The mentioned potentialities were easy access to the health service, proximity to residence and bond between users and professionals:

For the patient, I think that care decentralization is a positive aspect, due to accessibility to the health system, it's much easier to get the medication near home, spending nothing on transportation (E05).

Class 5, Stigma and prejudice, is closely related to Class 1 , since it deals with barriers to treatment and HIV status acceptance by the patient, professionals, and community, with issues related to stigma and prejudice. Thus, fear of exposure of this health condition and communication of its diagnosis motivates disease denial by users, i.e., maintaining diagnosis secrecy prevents discrimination and/ or withdrawal from social life:

Prejudice against this disease is very strong and people would not look for treatment in primary care in order to prevent the community from knowing they have HIV (E02).

\section{DISCUSSION}

In PHC, the nurse plays a crucial function in assistance and follow-up of PLHIV.In this health space, the therapeutic bond promotes longitudinal and integral care to users, including diagnosis, domiciliary visits, preventive measures, and health promotion activities ${ }^{(12-14)}$. In the process of care decentralization, the ongoing necessity of overcoming some obstacles to fully implement care model reorganization is verified.

In the decentralization of care to PLHIV to PHC, barriers that compromise the consolidation of the transition process are pointed out. The literature emphasizes some negative aspects, i.e.: human resource deficit; increased workload; professional turnover; no training or support of matrix services; inappropriate physical structure; lack of material and supply ${ }^{(15-17)}$.

A study conducted in the city of Edinburgh, United Kingdom, identifies the preference of health users for specialized services as one of the barriers. People have difficulty in accepting PHC as basic in HIV care and sexual health screening. Efforts for the recognition of PHC are important to promote primary care expansion, guaranteeing equity of access to health services ${ }^{(18)}$.

In face of this, the discussed factors weakening the process of care decentralization are shown to be related to the social system of Imogene King's theory ${ }^{(9)}$ concerning the structural flaws in the organization of a care model, 
which has consequences for the work process of the FHS in PHC and the quality of services offered to health users. The identification of flaws in the current model is of utmost importance for redefinition of attributions and planning, with the objective of supporting manager decision-making, in agreement with the diverse involved actors (users, professionals, and social control) in the process of collective construction.

Also in relation to barriers, the geographic proximity of $\mathrm{PHC}$ is an obstacle to the process of decentralization of care attributed to lack of privacy, in addition to stigma, exposure, fear of disclosure of confidential diagnosis, maltreatment by part of the professionals, and excessive waiting for service $^{(19,20)}$.

However, this same territory proximity of $\mathrm{PHC}$ from the user residence is paradoxically pointed as a potentiality for model transition. As a positive aspect, it provides more access to the health unit, which facilitates the initial contact, the conduction of the RT, fast return of exam results, and actions for health promotion and prevention ${ }^{(21)}$.

Corroborating the literature, utterances by nurses in this study have emphasized the unit within the community, near the user's living area, as a positive aspect, implying a lower financial cost, given that the patient is not required to commute to other distant services. This ratifies PHC as an important health environment among the levels of complexity and leads to a chain of positive actions and reactions in healthcare.

Confirming these findings, a study conducted in Vietnam has shown that integration of the primary health level promotes proximity between healthcare and domiciles, particularly in geographically difficult areas, which facilitates population access to the health system, creating a viable and sustainable model ${ }^{(22)}$.

In this perspective, RT, within PHC, plays a fundamental role in the transition of health conducts, as it represents an advance in the deconstruction of centralization of diagnosis. The insertion of the RT in PHC is shown to be a strategic intervention to decentralize care to PLHIV. This evidence implies an increased promptness and optimization of HIV results, while also reinforcing the integration among health system levels. This advancement is observed to have positive impacts on the reorganization of the healthcare model, particularly in the local level ${ }^{(23)}$.

In the content of Class 1 , presented in the results, it was noted that, although the RT is considered the user's entrance into $\mathrm{PHC}$, there are still significant barriers to the process of diagnosis disclosure. Insecurity when communicating a positive result was pointed out in the participants' statements as an obstacle to healthcare, with effects on the therapeutic bond between professional and patient.

Concerning professional trainings, this study and the literature identify that the education process must enhance competences and skills through improvement, critical reflection, and established knowledge $\mathrm{e}^{(24)}$, to raise consciousness of care practices, considering technical knowledge against reality. This fact is in agreement with a study dealing with care provided in primary services concerning HIV. In this sense, professional training has an impact on the nurse's work and care to PLHIV while showing that some obstacles to performance and integration of care at services are associated to function performance and care management $t^{(17)}$.

A study conducted in a community health center in China, which aimed at describing practices related to the HIV test and the development of activities in primary level services, has emphasized that only one third of the nurses participating in the study were trained for HIV diagnosis. Therefore, training deficit was observed to have consequences for the execution and coverage of RT, in addition to perpetuating stigmatizing attitudes ${ }^{(25)}$.

The utterances of nurses in this study emphasize the predominance of aspects and repercussions of stigma and prejudice in the life of PLHIV, their respective relatives and health professionals involved in care, which was represented by Classes 1 and 5, which included utterances related to fear, pain, exclusion, exposure, and denial upon the possibility of a positive HIV diagnosis, feelings which may delay the access of PLHIV to health services.

Overall, acceptance of health condition, prevention and health promotion, consultation, and treatment may pose negative effects due to an ongoing reality of stigma and prejudice $^{(26,27)}$

The experiences in HIV management are noticed to provoke significant changes in the attitudes of the professionals, which corroborates and refers to reflections on the importance of trainings and matrix support as positive factors both for fighting HIV and breaking with stigmatizing conducts.

Still from the perspective of the impact of trainings, it is possible to infer that, through preventive measures in the Class 3 of the study, qualified professionals take advantage of the health environments for developing strategic actions and health education aiming at disseminating knowledge and orientation to health users. Thus, knowledge and experience sharing have the power of resignifying attitudes towards HIV.

In this context, the therapeutic bond between nurse and care receivers, established through communication, is emphasized as a potentiality to strengthen information sharing and confidence on care planning. The interpersonal relations of subjects cross-section in moments of imbalance and stress, thus directing quality care actions whose goals will have a higher chance of being fulfilled ${ }^{(28)}$. Thus, when PLHIV are observed within PHC, the interpersonal system of the Theory of Goal Attainment reinforces a holist outlook towards the patient, beyond the disease context.

Gaps are pointed out in the utterances of most nurses participating in this study. Trainings are a thematic limitation, since they are focused on RT performance, reducing the integral care process to diagnosis. Integral success of effective decentralization of PLHIV care in the $\mathrm{PHC}$ is thus hindered.

The gaps include the fact that when training is offered to the FHS team, they are directed at the FHU nurses, making this professional category thus responsible for the success of implementation of this service in the territory. 
This restriction is observed to rupture interpersonal relations among team members, leading to a deficit in the commitment and engagement of all members in PLHIV care and overloading one professional category. Efforts for renegotiation of manager planning are important for sensibilizing the multiprofessional team to an integral approach to health.

Study limitations include the fact that it has considered only the viewpoint of the PHC nurses. In this sense, the conduction of new studies on the process of assessment of the decentralization degree from the perspective of all the professionals in the FHU, as well as from the perspective of users in relation to care offered to PLHIV at this complexity level is suggested.

\section{CONCLUSION}

This study's findings point out challenges in the transition of healthcare model offered to People Living with HIV in Primary Health Care, in accordance with perceptions of
Family Health Strategy nurses. The process of decentralization of care to the local level will promote a broadened access of users to health systems due to the proximity between services and the patient's houses, as well as integrality with other complexity levels. In addition, the performance of FHU nurses is emphasized as important for the concretization and reorganization of the care model.

Despite the advancements, follow-up and care to People Living with HIV are noticed to be still incipient in Primary Health Care, having as a framework the social and organizational system of the interactive system of Imogene King's Theory of Goal Attainment, enabling thus to demonstrate that gaps hinder the consolidation of the decentralization of the policy of care to people living with HIV.

Thus, efforts are necessary to plan the municipal management for fighting barriers that permeate care management, such as physical structure of units, availability of input, establishment of network flows, strengthening and training of human resources.

\section{RESUMO}

Objetivo: Analisar as percepções de enfermeiros sobre a descentralização do atendimento às pessoas vivendo com HIV. Método: Estudo exploratório, descritivo, com abordagem qualitativa, realizado com enfermeiros da atenção primária à saúde, fundamentado pela Teoria dos Sistemas Abertos de Imogene King (pessoal, interpessoal e social). Os dados foram obtidos por meio de entrevista; utilizou-se questionário sociodemográfico/profissional e roteiro semiestruturado, processados pelo software IRAMUTEQe analisados pela Classificação Hierárquica Descendente. Resultados: Participaram do estudo 32 enfermeiros. Emergiram da análise cinco classes: "processo de revelação diagnóstica"; "capacitação dos profissionais"; "medidas preventivas"; "barreiras e potencialidades no processo de descentralização"; e "estigma e preconceito". Conclusão: No processo de reorganização do modelo de assistência à saúde das pessoas vivendo com HIV na atenção primária à saúde, aponta-se importante contribuição do enfermeiro no fortalecimento da descentralização do atendimento no nível local.

\section{DESCRITORES}

HIV; Síndrome de Imunodeficiência Adquirida; Atenção Primária à Saúde; Enfermagem.

\section{RESUMEN}

Objetivo: Analizar las percepciones de los enfermeros sobre la descentralización de la atención a las personas que viven con el VIH. Método: Estudio exploratorio, descriptivo, con enfoque cualitativo, realizado con enfermeros de la atención primaria de salud, basado en la Teoría de los Sistemas Abiertos de Imogene King (personal, interpersonal y social). Los datos se obtuvieron por medio de una entrevista; se utilizaron un cuestionario sociodemográfico/profesional y un guion semiestructurado, procesados por el software IRAMUTEQy analizados por la Clasificación Jerárquica Descendente. Resultados: Los participantes del estudio fueron 32 enfermeros. Del análisis surgieron cinco clases: proceso de revelación del diagnóstico"; "formación de los profesionales"; "medidas preventivas"; "barreras y potencialidades en el proceso de descentralización"; y "estigma y prejuicio". Conclusión: En el proceso de reorganización del modelo de asistencia a la salud de las personas que viven con el VIH en la atención primaria de salud, se enfatiza la contribución de los enfermeros al fortalecimiento de la descentralización de la atención a nivel local.

\section{DESCRIPTORES}

VIH; Síndrome de Inmunodeficiencia Adquirida; Atención Primaria de Salud; Enfermería.

\section{REFERENCES}

1. Brasil. Ministério da Saúde. Cinco passos para a prevenção combinada ao HIV na Atenção Básica [Internet]. Brasília; 2017 [cited 2020 Mar 25]. Available from: http://www.aids.gov.br/pt-br/pub/2014/5-passos-para-implementacao-do-manejo-dainfeccao-pelo-hiv-naatencao-basica.

2. Colaço AD, Meirelles BHS, Heidemann ITSB, Villarinho MV. O cuidado à pessoa que vive com HIV/AIDS na atenção primária à saúde. Texto Contexto - Enferm. 2019;28:e20170339. DOI: https://doi.org/10.1590/1980-265x-tce-2017-0339.

3. Melo EA, Maksud I, Agostini R. Cuidado. HIV/Aids e atenção primária no Brasil: desafio para a atenção no Sistema Único de Saúde? Rev Panam Salud Pública. 2018;421:e151. DOI: https://doi.org/10.26633/RPSP.2018.151.

4. Lima MCL, Pinho CM, Silva MAS, Dourado CARO, Simplicio MRR, Santos JTC, et al. Protagonismo do enfermeiro da atenção básica na descentralização da assistência à pessoa vivendo com hiv/AIDS. Int J Dev Res. 2020;10(7):37860-3. DOI: https://doi.org/10.37118/ ijdr.19384.07.2020.

5. Abongomera G, Chiwaula L, Revill P, Mabugu T, Tumwesige E, Nkhata M, Cataldo F, et al. Patients-level benefits associated with decentralization of antirretroviral therapy services to primary health facilities in Malawi and Uganda. Int Health. 2018;10(1):8-19. DOI: https://doi.org/10.1093/inthealth/ihx061. 
6. Bilinski A, Birru E, Peckarsky M, Herce M, Kalanga N, Neumann C, et al. Distance to cara, enrollment and loss to follow-up of HIV patients during decentralization of antirretroviral therapy in Neno District, Malawi. A retrospective cohort study. PLoS ONE. 2017;12(10):e0185699. DOI: https://doi.org/10.1371/journal.pone.0185699.

7. Abongomera G, Kiwuwa-Muyingo S, Revill P, Chiwaula L, Mabugu T, Phillips AN, et al. Impact of descentralisation of antirretroviral therapy services on HIV testing and careat a population level in Agago Districtinrural Northern Uganda: results from the lablite population surveys. Int Health. 2017;9(2):91-9. DOI: https://doi.org/10.1093/inthealth/ihx006.

8. Onwujekwe O, Chikeziel M, Bachu C, Chiegil R, Torpey K, Uzochukwu B. Investigating cliente perception and atitudetodes centralization of HIV/Aids treatment services to primary health centres in three Nigerianstates. Health Expect. 2016;19(5):1111-20. DOI: https://doi. org/10.1111/hex.12403.

9. King, I. A theory for nursing: systems, concepts, process. New York: Wiley Medical Publications; 1981.

10. Camargo BV, Justo AM. Tutorial para uso do software IRAMUTEQ [Internet]. Porto Alegre: UFSC; 2018 [cited 2020 Mar 25]. Available from: http://iramuteq.org/documentation/fichiers/tutoriel-portugais-22-11-2018.

11. Bardin L. Análise de conteúdo. São Paulo: Edições 70; 2011.

12. Ngunyulu RN, Peu MD, Mulaudzi FM, Mataboge MLS, Phiri SS. Collaborative HIV care in primary health care: nurses' views. Int Nurs Rev. 2017;64(4):561-7. DOI: https://doi.org/10.1111/inr.12359.

13. Dumitru G, Irwin K, Tailor A. Updated Federal Recommendations for HIV Prevention With Adults and Adolescents With HIV in The United States: The Pivotal Role of Nurses. J Assoc Nurses AIDS Care. 2017;28(1):8-18. DOI: https://doi.org/10.1016/j.jana.2016.09.011.

14. Dawson-Rose C, Cuca YP, Webel AR, Báez SSS, Holzemer WL, Rivero-Méndez M, et al. Building Trust and Relationships Between Patients and Providers: An Essential Complement to Health Literacy in HIV Care. J Assoc Nurses AIDS Care. 2016;27(5):574-84. DOI: https://doi. org/10.1016/j.jana.2016.03.001.

15. Zambenedetti G, Silva RAN. Descentralização da atenção em HIV-Aids para a atenção básica: tensões e potencialidades. Physis. 2016;26(3):785-806. DOI: https://doi.org/10.1590/S0103-73312016000300005.

16. Araújo WJ, Quirino EMB, Pinho CM, Andrade MS. Percepção de enfermeiros executores de teste rápido em Unidades Básicas de Saúde. Rev Bras Enferm. 2018;71(Suppl 1):631-6. DOI: https://doi.org/10.1590/0034-7167-2017-0298.

17. Rocha GSA, Andrade MS, Silva DMR, Terra MG, Medeiros SEG, Aquino JM. Sentimentos de prazer no trabalho das enfermeiras na atenção básica. Rev Bras Enferm. 2019;72(4):1036-43. DOI: http://dx.doi.org/10.1590/0034-7167-2018-0518.

18. Maxwell S. General Practitioners' views and experiences on the barriers and facilitators that men who have sex with men have when accessing primary care for HIV testing and sexual health screening. Prim Health Care Res Dev. 2018;19(2):205-9. DOI: https://doi. org/10.1017/S1463423617000627.

19. Abongomera G, Kiwuwa-Muyingo S, Revill P, Chiwaula L, Mabugu T, Phillips A, et al. Population level usage of health services, and HIV testing and care, prior to decentralization of antiretroviral therapy in Agago District in rural Northern Uganda. BMC Health Serv Res. 2015;15(1):527. DOI: https://doi.org/10.1186/s12913-015-1194-4.

20. Becker N, Cordeiro LS, Poudel KC, Sibiya TE, Sayer AG, Sibeko LN. Individual, household, and Community level barriers adherence among women in rural Eswatini. PLoS ONE. 2020;15(4):e0231952. DOI: https://doi.org/10.1371/journal.pone.0231952.

21. Zambenedetti G, Silva RAN. The paradox of the territory and the stigmatization processes regarding access to HIV diagnosis in Primary Health Care. Estud Psicol. 2015;20(4):229-40. DOI: https://doi.org/10.5935/1678-4669.20150024.

22. Nguyen VTT, Best S, Pham HT, Troung TXL, Hoang TTH, Wilson K, et al. HIV point of care diagnosis: preventing misdiagnosis experience from a pilot of rapid test algorithm implementation in selected communes in Vietnam. J Int AIDS Soc. 2017;20(Suppl):21752. DOI: https:// doi.org/10.7448/IAS.20.7.21752.

23. Naik R, Zembe W, Adigun F, Jackson E, Tabana H, Jackson D, Feeley F, et al. What Influences Linkage to Care After Home-Based HIV Counseling and Testing? AIDS Behav. 2018;22(3):722-32. DOI: https://doi.org/10.1007/s10461-017-1830-6.

24. Santos TS, Bragagnollo GR, Tavares CM, Papaléo LK, Carvalho LWT, Camargo RAA. Qualificação profissional de enfermeiros da atenção primária à saúde e hospitalar: um estudo comparativo. Rev Cuid. 2020;11(2):e786. DOI: https://doi.org/10.15649/cuidarte.786.

25. Ong JJ, Peng MH, Wong WW, Ying-Ru L, Kidd MR, Roland M, et al. Opportunities and barriers for providing HIV testing through community health centers in mainland China: a nationwide cross-sectional 96 survey. BMC Infect Dis. 2019;19(1):1054. DOI: https:// doi.org/10.1186/s12879-019-4673-0.

26. McNair OS, Gipson JA, Denson D, Thompson DV, Sutton MY, Hickson DA, et al. The Associations of Resilience and HIV Risk Behaviors Among Black Gay, Bisexual, Other Men Who Have Sex with Men (MSM) in the Deep South: The MARI Study. AIDS Behav. 2018;22: 1679-87. DOI: https://doi.org/10.1007/s10461-017-1881-8.

27. Eaton LA, Earnshaw VA, Maksut JL, Katherine R, Thorson KR, Watson RJ, et al. Experiences of stigma and health care engagement among Black MSM newly diagnosed with HIV/STI. J Behav Med. 2018;41(4):458-66. DOI: https://doi.org/10.1007/s10865-018-9922-y.

28. Borges JWP, Moreira TMM, Menezes AVB, Loureiro AMO, Carvalho IS, Florêncio RS. Compreensão da relação interpessoal enfermeiropaciente em uma unidade de atenção primária fundamentada em Imogene King. Rev Enferm Cent-Oeste Min. 2019;9. DOI: https://doi. org/10.19175/recom.v9i0.3011. 